Eckhard Hein and Achim Truger, Macroeconomic Policy Institute (IMK) in the Hans Boeckler Foundation

\title{
Monetary policy, macroeconomic policy mix and economic performance in the Euro area
}




\title{
Monetary policy, macroeconomic policy mix and economic performance in the Euro area
}

\author{
Eckhard Hein and Achim Truger* \\ Macroeconomic Policy Institute (IMK) in the Hans Boeckler Foundation
}

\begin{abstract}
In order to explain slow growth and high unemployment in the Euro area, in particular if compared to the USA, we follow a macroeconomic policy view focussing on the more restrictive stance of monetary, fiscal and wage policies in the Euro area. In the present paper we focus on the particular role of monetary policy, because the European Central Bank (ECB) seems to be the major obstacle to higher growth and employment. Analysing the macroeconomic policy mix, wage policies and fiscal policies are taken into account at the outset, but then the determinants of ECB policies are assessed in more detail. Our analysis confirms that it is the ECB's overemphasising a too low inflation target which is a major problem for macroeconomic performance in the Euro area. The ECB is too exclusively occupied with inflation and wage developments and pays too little attention to the development of real variables. In order to improve growth and employment and to limit the risks of deflation in the largest economy of the Euro area, Germany, it is therefore required that the ECB raises its inflation target and that the central bank focuses more on real economic activity.
\end{abstract}

JEL-Code: E 52, E 58, E 61, E 63, E 65

Key words: Monetary policy, macroeconomic policy mix, Euro area

Corresponding author

PD Dr. Eckhard Hein

IMK in der Hans Boeckler Stiftung

Hans Boeckler Str. 39

40476 Duesseldorf

Germany

e-mail: eckhard-hein@boeckler.de

\footnotetext{
*We are grateful to Sabine Stephan for helpful comments on the econometrics. Remaining errors are, of course, ours.
} 


\section{Introduction}

Since the growth slowdown in 2000/1, the Euro area has had a difficult time to recover and macroeconomic performance has been worse than in the USA. There the economy returned rather quickly to its late 1990s growth path. On average over the period 2001-2005, annual real GDPgrowth in the Euro area has remained more than 1 percentage point below US-growth (Table 1). The growth differential between these two large currency areas already to be found since the mid1990s (Hein/Niechoj 2006), the start of the convergence process towards the European Monetary Union (EMU), seems to become persistent. Whereas the USA is heavily relying on prosperous domestic demand and accepts a negative growth contribution of external balances, the Euro area as a whole displays a more balanced picture, albeit on a lower level: The lower growth is relying on domestic demand with a positive but small growth contribution of foreign balances. Although employment has been growing at a similar rate as in the USA - due to lower productivity growth in the Euro area -, the unemployment rate in the Euro area is still considerably above the US level. Between 2001 and 2005, inflation in the Euro area has on average slightly exceeded the inflation target of the European Central Bank (ECB) of 'below, but close to, 2 percent in the medium term' (ECB 2003: 79). But the deviation from the US inflation rate is rather small. Taken together, in the recent years the US economy has once more managed to combine reasonable growth, low unemployment and low inflation in a far better manner than the Euro area, similar to the 1990s.

Slow growth and high unemployment are by no means equally distributed across the Euro area. Whereas during the period 2001-2005 in particular the large economies Germany and Italy, together with the Netherlands and Portugal, have been suffering from real GDP growth rates well below the Euro area average, Spain, Finland, Greece and Ireland have experienced growth considerably above this average. Spain, Ireland and Greece have had even higher growth rates than the USA. France, Austria and Belgium have grown with Euro area average rates. And also the unemployment rates display a wide dispersion across Euro area countries with particularly low rates in Austria, Ireland, the Netherlands and Portugal and well above Euro area average rates in France, Spain and Greece. Unemployment in Austria, Ireland and the Netherlands has been even below the US level. And finally we find that also inflation rates show major differences between Euro area countries, with rates well below the ECB's target in Germany and Finland, with rates close to this target in France, Belgium and Austria, and with inflation rates well above the ECB's target rate in Spain, Greece, Ireland, the Netherlands and Portugal. 


\begin{tabular}{|c|c|c|c|c|c|c|c|c|c|c|c|c|c|}
\hline & $\begin{array}{l}\text { Ger- } \\
\text { many }\end{array}$ & France & Italy & Spain & Austria & Belgium & Finland & Greece & Ireland & $\begin{array}{c}\text { Nether- } \\
\text { lands }\end{array}$ & Portugal & $\begin{array}{c}\text { Euro } \\
\text { area }\end{array}$ & $\overline{\text { USA }}$ \\
\hline $\begin{array}{l}\text { Real GDP, annual growth } \\
\text { rate, percent }\end{array}$ & 0.7 & 1.6 & 0.8 & 3.1 & 1.5 & 1.5 & 2.2 & 4.2 & 5.1 & 0.7 & 0.6 & 1.4 & 2.6 \\
\hline $\begin{array}{l}\text { Growth contribution of } \\
\text { domestic demand } \\
\text { including stocks, } \\
\text { percentage points }\end{array}$ & -0.3 & 2.1 & 1.1 & 4.2 & 0.7 & 1.3 & 2.0 & 4.3 & 3.9 & 0.4 & 0.3 & 1.3 & 3.0 \\
\hline $\begin{array}{l}\text { Growth contribution of } \\
\text { private consumption, } \\
\text { percentage points }\end{array}$ & 0.2 & 1.2 & 0.6 & 2.0 & 0.5 & 0.6 & 1.4 & 2.5 & 1.9 & 0.2 & 0.8 & 0.8 & 2.2 \\
\hline $\begin{array}{l}\text { Growth contribution of } \\
\text { public consumption, } \\
\text { percentage points }\end{array}$ & 0.0 & 0.5 & 0.3 & 0.8 & 0.1 & 0.5 & 0.5 & 0.3 & 0.8 & 0.5 & 0.4 & 0.3 & 0.5 \\
\hline $\begin{array}{l}\text { Growth contribution of } \\
\text { gross fixed capital } \\
\text { formation, percentage } \\
\text { points }\end{array}$ & -0.4 & 0.3 & 0.1 & 1.3 & 0.0 & 0.3 & 0.2 & 1.6 & 1.1 & -0.1 & -0.9 & 0.1 & 0.4 \\
\hline $\begin{array}{l}\text { Growth contribution of } \\
\text { balance of goods and } \\
\text { services, percentage } \\
\text { points }\end{array}$ & 1.0 & -0.4 & -0.4 & -1.0 & 0.8 & 0.2 & 0.2 & -0.1 & 1.3 & 0.3 & 0.3 & 0.1 & -0.5 \\
\hline $\begin{array}{l}\text { Employment, annual } \\
\text { growth, percent }\end{array}$ & -0.1 & 0.5 & 1.2 & 3.1 & 0.2 & 0.5 & 0.8 & 1.0 & 2.7 & 0.0 & 0.4 & 0.8 & 0.7 \\
\hline $\begin{array}{l}\text { Unemployment rate, } \\
\text { percent }\end{array}$ & 8.7 & 9.2 & 8.4 & 10.8 & 4.4 & 7.6 & 8.9 & 10.3 & 4.3 & 3.7 & 5.9 & 8.5 & 5.4 \\
\hline $\begin{array}{l}\text { Inflation rate (HCPI), } \\
\text { percent }\end{array}$ & 1.6 & 2.0 & 2.4 & 3.2 & 1.9 & 2.0 & 1.4 & 3.5 & 3.5 & 2.9 & 3.2 & 2.2 & 2.5 \\
\hline
\end{tabular}

In order to explain the long-run growth and employment differences between the Euro area and the USA, we have put forward a macroeconomic policy view focussing on the more restrictive stance of monetary, fiscal and wage policies in the Euro area compared to the macroeconomic policy regime in the USA. ${ }^{1}$ In the present paper we will focus on the particular role of monetary policy. Interaction with wage policies and fiscal policies will be taken into account at the outset. But then the determinants of ECB policies will be assessed in detail.

As is well known, whereas monetary policy has been centralised within the Euro area and has now been run by the ECB since 1999, fiscal and wage policies have not been centralised. Regarding wage policies, the Maastricht regime and in particular the 'Employment Guidelines' and the 'Broad Economic Policy Guidelines' exert strong pressure towards further decentralisation of wage bargaining and deregulation of the labour market exacerbating the general tendencies in this field and making it increasingly difficult to coordinate wage policies across the Euro area with an eye to

\footnotetext{
${ }^{1}$ See Hein/Truger (2005a, 2005b) on the Maastricht regime, Hein/Truger (2005c, 2005d) on the special situation of the German economy and Hein/Truger (2006a), Hein/Schulten/Truger (2006) on the risks of deflation in Germany and Europe associated with this constellation. Also Fritsche et al. (2005), Palley (1998) and Solow (2000) have argued that a favourable coordination between monetary and fiscal policies rather than deregulated labour markets can be held responsible for the superior development of the US-economy during the 1990s compared to Germany or the EU.
} 
its macroeconomic effects. ${ }^{2}$ Fiscal policy remains essentially a matter of national responsibility and is co-ordinated through the 'Treaty of Maastricht' and the 'Amsterdam Stability and Growth Pact' (SGP). As conditions of entry to the monetary union, the Maastricht Treaty has set a maximum deficit ratio (proportion of current budget deficit in relation to GDP) of 3 percent and a maximum debt ratio (proportion of public debt in relation to GDP) of 60 percent. The SGP makes this regulation even tougher by prescribing for the medium term, i.e. a time span which stretches across economic cycles, balanced budgets or even budget surpluses in order to reduce the level of debt. ${ }^{3}$ During the low growth, high unemployment period 2001-2005, more and more countries have failed to comply with the regulations of the SGP. This has led to at least some modifications in the application of the SGP in 2005. In our view, however, these do not go far enough in order to allow fiscal policies to stabilise economic development in the Euro area. ${ }^{4}$

The paper is organised as follows. We address the macroeconomic policy mix in the Euro area in the period 2001-2005 in Section 2. In Section 3 we take a closer look at monetary policies since 1999. We try to identify the determinants of the ECB's monetary policy decisions by means of estimating 'naïve' and expanded Taylor rules. In Section 4 we apply and interpret our estimation results against the background of the course of ECB policies since 1999, and Section 5 draws some brief economic policy conclusions.

\section{The stance of monetary, fiscal and wage policies 2001-2005}

Monetary policy can be assessed by the development of the short-term real interest rate. It is now widely accepted that modern central banks use the short-term nominal interest rate as an economic policy instrument. But if central banks target inflation, they have to set nominal interest rates with an eye to the ensuing real rate, as it is proposed in the famous Taylor-rule for example (Taylor 1993). ${ }^{5}$ In this section we refrain from applying pre-determined Taylor-rules in order to assess the monetary policy stance, ${ }^{6}$ because we doubt that the 'equilibrium real interest rate' underlying Taylor-rules is independent of monetary policies. The same problem of endogeneity arises with respect to potential output which is required to calculate the output gap as one of the determinants

\footnotetext{
${ }^{2}$ See Hein/Niechoj (2006) on the Broad Economic Policy Guidelines and Hein/Schulten (2004) on wage bargaining and wage developments in the European Union.

${ }^{3}$ See Allsopp/Vines (1998), Arestis et al. (2001) and Eichengreen (1998) for a critical assessment of the SGP.

${ }^{4}$ See Hein/Truger (2006b) for a detailed analysis of fiscal policies in the EMU.

${ }^{5}$ This is the way monetary policy is introduced in the now prevalent New Consensus models. See Goodfried/King (1997), Clarida/Gali/Gertler (1999), Romer (2000), Taylor (2000) and Carlin/Soskice (2006).

${ }^{6}$ See Arestis/Chortareas (2006) for such an exercise and a discussion of some of the related problems.
} 
of monetary policy. In Section 3 we will estimate ex-post monetary policy rules for the ECB since 1999 and will address these problems in more detail.

In order to discuss the macroeconomic effects of monetary policy's real interest rate variations in a compact way, we consult the differences between the short-term real interest rate and real GDPgrowth and also the difference between the long-term real interest rate and real GDP-growth. We expect a negative influence of real interest rates on economic growth working through different transmission channels (money, credit, asset prices, exchange rates) (Bernanke/Gertler 1995, Cecchetti 1995).

\begin{tabular}{|c|c|c|c|c|c|c|c|c|c|c|c|c|c|}
\hline & \begin{tabular}{|c|} 
Ger- \\
many
\end{tabular} & France & Italy & Spain & Austria & Belgium & Finland & Greece & Ireland & $\begin{array}{c}\text { Nether- } \\
\text { lands }\end{array}$ & Portugal & $\begin{array}{c}\text { Euro } \\
\text { area }\end{array}$ & USA \\
\hline \multicolumn{14}{|l|}{ Monetary Policy } \\
\hline Short-term real interest rate, percent & 1.2 & 0.8 & 0.4 & -0.4 & 0.9 & 0.8 & 1.4 & -0.7 & -0.6 & 0.0 & -0.4 & 0.6 & -0.2 \\
\hline Long-term real interest rate, percent & 2.6 & 2.3 & 2.0 & 1.1 & 2.5 & 2.3 & 2.9 & 1.0 & 0.9 & 1.4 & 1.2 & 2.1 & 1.9 \\
\hline $\begin{array}{l}\text { Short-term real interest rate minus real } \\
\text { GDP growth, percentage points }\end{array}$ & 0.5 & -0.8 & -0.4 & -3.5 & -0.5 & -0.7 & -0.8 & -4.9 & -5.7 & -0.8 & -1.0 & -0.8 & -2.7 \\
\hline $\begin{array}{l}\text { Long-term real interest rate minus real } \\
\text { GDP growth, percentage points }\end{array}$ & 1.9 & 0.7 & 1.3 & -2.0 & 1.0 & 0.8 & 0.7 & -3.3 & -4.3 & 0.7 & 0.6 & 0.7 & -0.7 \\
\hline \multicolumn{14}{|l|}{ Wage Policy } \\
\hline $\begin{array}{l}\text { Nominal compensation per employee, } \\
\text { annual growth, percent }\end{array}$ & 1.7 & 2.7 & 3.1 & 3.3 & 2.0 & 2.8 & 3.2 & 6.5 & 5.7 & 3.9 & 2.3 & 2.5 & 4.0 \\
\hline $\begin{array}{l}\text { Nominal unit labour costs, annual } \\
\text { growth, percent }\end{array}$ & 0.3 & 1.7 & 3.2 & 2.9 & 0.8 & 1.8 & 1.8 & 3.3 & 3.3 & 2.7 & 2.1 & 1.7 & 1.7 \\
\hline Labour income share $\#$, percent & 58.1 & 57.4 & 55.6 & 57.1 & 62.5 & 61.7 & 55.6 & 58.0 & 47.8 & 59.2 & 63.0 & 58.0 & 62.6 \\
\hline $\begin{array}{l}\text { Change in labour income share to } \\
\text { previous year, percentage points }\end{array}$ & -0.5 & 0.0 & 0.2 & -0.5 & -0.6 & -0.2 & 0.5 & -0.2 & -0.2 & 0.0 & -0.6 & -0.2 & -0.4 \\
\hline \multicolumn{14}{|l|}{ Fiscal Policy } \\
\hline $\begin{array}{l}\text { Cyclically adjusted budget balance } \\
\text { (percent of cyclically adjusted GDP), } \\
\text { annual change, percentage points }\end{array}$ & -0.1 & -0.1 & -0.3 & 0.3 & 0.4 & 0.3 & -0.8 & -0.2 & -0.8 & 0.1 & 0.1 & -0.1 & -0.9 \\
\hline $\begin{array}{l}\text { Output gap, (percent of cyclically } \\
\text { adjusted GDP), annual change, } \\
\text { percentage points }\end{array}$ & -0.8 & -0.5 & -0.5 & -0.1 & -1.0 & -0.5 & -0.5 & 0.4 & -0.8 & -1.4 & -1.4 & -0.6 & -0.3 \\
\hline $\begin{array}{l}\text { Number of years with pro-cyclical } \\
\text { fiscal policy during an economic } \\
\text { slowdown }\end{array}$ & \begin{tabular}{|c|}
3 \\
$(2003-$ \\
$2005)$
\end{tabular} & \begin{tabular}{c|}
1 \\
-2005
\end{tabular} & $\begin{array}{c}3 \\
(2002- \\
2004)\end{array}$ & $\begin{array}{c}2 \\
(2002- \\
2003)\end{array}$ & $\begin{array}{c}3 \\
(2001- \\
2002 \\
2004)\end{array}$ & $\begin{array}{c}4 \\
\text { (2001- } \\
2003 ; \\
2005)\end{array}$ & \begin{tabular}{c|}
1 \\
-2005
\end{tabular} & $\begin{array}{c}1 \\
-2005\end{array}$ & $\begin{array}{c}2 \\
(2003- \\
2004)\end{array}$ & $\begin{array}{c}2 \\
(2003, \\
2005)\end{array}$ & $\begin{array}{c}3 \\
(2002- \\
2004)\end{array}$ & $\begin{array}{c}3 \\
(2003- \\
2005)\end{array}$ & 0 \\
\hline $\begin{array}{l}\text { Negative fiscal stimulus in economic } \\
\text { slowdown, cumulated (percent of } \\
\text { potential GDP) }\end{array}$ & 1.1 & 0.5 & 0.8 & 0.9 & 3.0 & 1.9 & 0.5 & 2.2 & 2.8 & 1.2 & 3.8 & 0.5 & -- \\
\hline
\end{tabular}




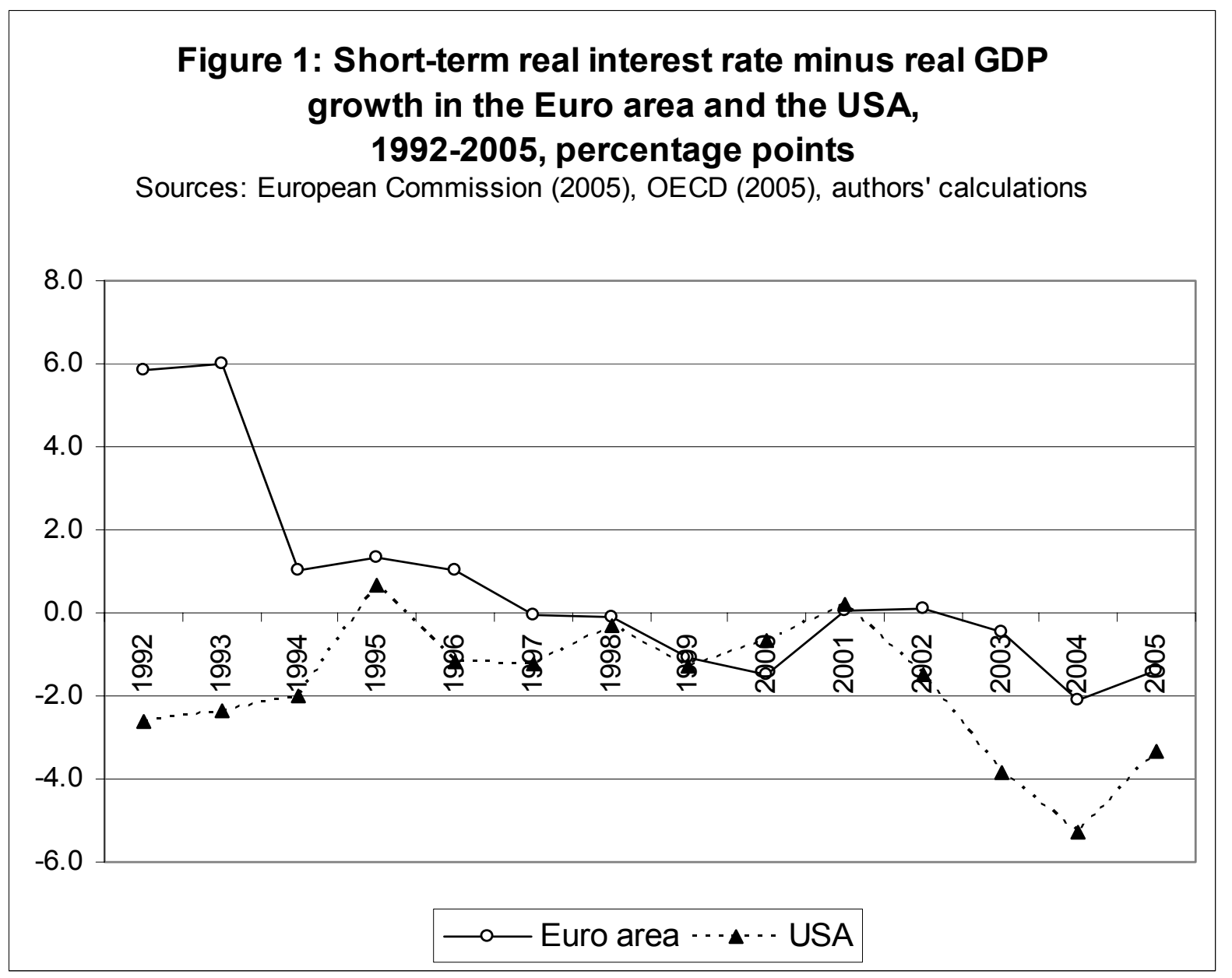

Whereas the Euro area short-term real interest rate has been positive on average over the period after the 2000/1 growth slowdown, the Federal Reserve (Fed) has managed to establish a negative short-term real interest rate of -0.2 percent in the USA (Table 2). These expansionary monetary policies have contributed to the quick recovery of the US economy. Already in 2002 the USA saw again - as in the years before 2001 - a negative short-term real interest rate-real GDP growth ratedifference, whereas in the Euro area this difference has become negative only in 2003 (Figure 1). On average over the period 2001-2005, the Fed established a favourable short-term real interest rate-real GDP growth-difference (-2.7 percentage points), and also a growth-friendly long-term real interest rate-real GDP growth constellation (-0.7 percentage points). The ECB has been much more reluctant to stimulate the economy by means of cutting interest rates in the face of the $2000 / 1$ slowdown and has thereby contributed to weak growth in the Euro area. Whereas on average over the period 2001-2005 in the Euro area as a whole the short-term real interest rate-real GDP growthdifference was at least slightly negative (-0.8 percentage point), the long-term real interest rate-real GDP growth-difference remained positive (0.7 percentage points). 
The ECB policy has been particularly harmful for the largest member country, Germany (Table 2). As the German inflation rate has been lower than the EMU average and the nominal interest rates have almost completely converged since 1999, Germany's real interest rates have even been higher than the Euro area average since then. And this has contributed to an unfavourable short-term real interest rate-real GDP growth-difference, which among the Euro area countries remains positive only in Germany on average over the period 2001-2005. On the other hand, the high inflation countries Spain, Greece, Ireland, and to a lesser extent even Portugal, have had negative short-term real interest rates and a very growth conducive constellation with negative differences between the short-term real interest rate and real GDP growth and also negative long-term real interest rate-real GDP growth-differences (except Portugal).

Therefore, the ECB's 'anti-growth-bias', i.e. a too restrictive definition of price stability for the heterogeneous currency area and an asymmetric response to the expected deviation of actual from target inflation, ${ }^{7}$ has contributed to the weak growth and employment performance of the Euro area as a whole and to the economic problems of the largest Euro area member, Germany, in particular. However, it has to be conceded that the ECB cannot react towards the inflation differences between Euro area member countries. This is where wage policies become relevant.

Wage policies can be assessed by nominal wage growth (compensation per employee), unit labour cost growth and the labour income share. Nominal wage setting affects unit labour cost growth and inflation. If nominal wages increase at a faster pace than productivity plus the price level, unit labour cost growth and inflation will speed up. This will cause real interest rates to fall and may make monetary policies intervene in order to stabilise inflation at some target rate. If nominal wages increase at a rate below the sum of productivity growth and inflation, unit labour cost growth will slow down and cause disinflation. Finally, deflation may be the result. Deflation causes increasing real interest rates and rising real debts with potentially negative effects on investment and growth. ${ }^{8}$ If deflationary processes have started, monetary policies lowering nominal interest rates will be ineffective.

Wage policies, however, may not only affect prices, but may also change distribution if firms do not completely pass unit labour cost variations to prices or if prices of other inputs do not change in step

\footnotetext{
${ }^{7}$ The ECB has tended to tighten whenever inflation increased above the target without relaxing when inflation expectations came down. For a general critique of the ECB's 'anti-growth bias' see Bibow (2002, 2005a, 2005b) and Hein (2002).

${ }^{8}$ See Arestis/Sawyer (2005) and Sawyer (2002) for recent post-Keynesian models of distribution conflict and inflation, and Hein $(2006 \mathrm{a}, 2006 \mathrm{~b})$ for the integration of real debt effects into Kaleckian models of distribution and growth with conflict inflation.
} 
with unit labour costs (Hein/Schulten/Truger 2006). Under these conditions, nominal wage moderation causes the labour income share to fall. Hypothetically, the effects of income shares on GDP growth are ambiguous (Bhaduri/Marglin 1990). With the propensity to save out of wages falling short of the savings propensity out of profits, a falling labour income share means a cut-back in consumption demand and capacity utilisation with directly contractive effects on investment and GDP growth. On the other hand, a fall in labour income shares that is associated with nominal wage restraint will improve international competitiveness and, therefore, stimulate demand for exports, investment and growth. With a slowdown in inflation, the central bank may also cut interest rates and stimulate investment and growth. Finally, a falling labour income share is associated with rising unit profits which may also improve investment and growth.

Since the stimulating effects of wage moderation and declining labour income shares for investment and growth are rather indirect and uncertain, in particular in large and rather closed economies as the Euro area and the USA, the direct and contractive effects will dominate presumably. And since nominal wage increases, which will shift distribution in favour of labour income will also trigger inflation and concomitant restrictive central bank interventions, nominal wage growth according to the sum of long-run productivity growth and the central bank's inflation and hence roughly constant labour income shares should be generally favourable conditions for growth and employment in large and rather closed currency areas.

On average over the period 2001-2005, nominal wage growth in the Euro area has been lagging behind the USA (Table 2). But taking into account productivity growth, nominal wage increases in both currency areas have been stability oriented: nominal unit labour costs have grown by 1.7 percent and have hence not caused any inflationary pressures. Moderate wage increases were accompanied by a decline in the labour income share, both in the Euro area and in the USA. Whereas in the USA this decline compensated for the increase in the previous years, generating a stationary trend since the early 1990s, in the Euro area the recent decline has continued the decreasing trend since the early 1990s (Figure 2). Although labour income shares were similar in the early 1990s, the Euro area value has plunged 4 percentage points below the US-value by now and has contributed to domestic demand problems. 


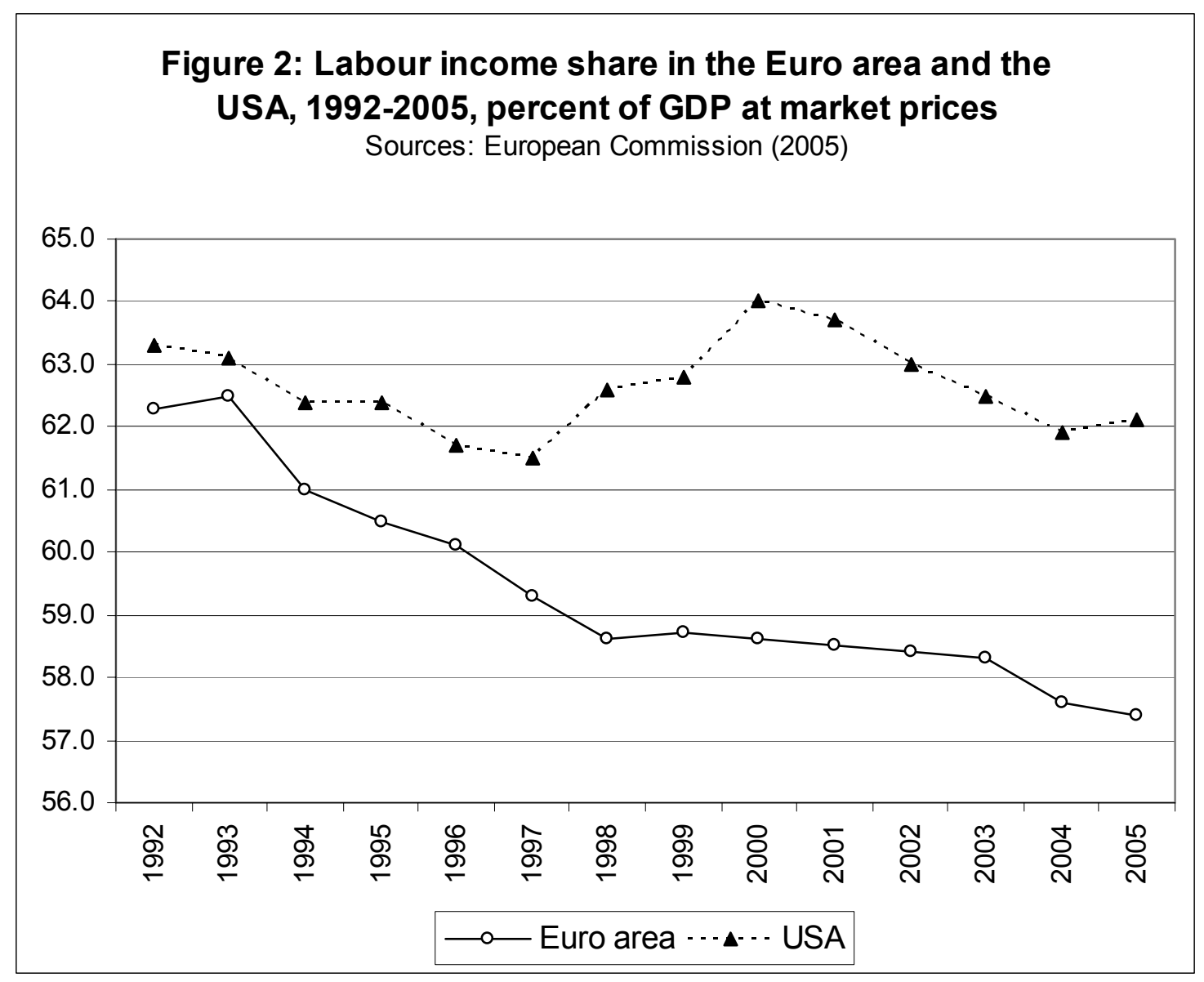

Below the surface of Euro area aggregate values we see a wide dispersion of wage and nominal unit labour costs developments (Table 2). In Italy, Spain, Greece, Ireland and the Netherlands nominal unit labour costs have grown at rates around 3 percent, which interfere with the ECB's inflation target. Nominal unit labour costs in Germany, however, and to a lesser extent in Austria, have grown at especially low rates causing deflationary risks, which have been accompanied by a rapid decline in labour income shares contributing to domestic demand problems. Especially the German wage development is completely inappropriate for the largest economy in a currency union: ${ }^{9}$ Overly moderate wage policies have improved price competitiveness and profitability of German firms and have made German export surpluses almost quadruple between 2001 and 2005. And since around 44 percent of German exports go to the Euro area, increasing German export surpluses cause major problems for the other Euro area countries. Whereas Germany has continuously increased its current account surplus, amounting to 4.1 percent of GDP in 2005, the other larger Euro area countries (France, Italy, Spain) have been driven into current account deficits (Table 3). And also some of the smaller countries either have seen their surpluses shrink (Belgium, Finland) or have not been able to decrease their huge deficits (Greece, Portugal). This constellation will inevitably push

\footnotetext{
${ }^{9}$ See Hein/Truger (2006a) for a more extensive discussion.
} 
the other Euro area countries to introduce deflationary wage policies as well, and hence the risk of deflation will spread across the Euro area.

\begin{tabular}{|l|c|c|c|c|c|}
\hline \multicolumn{5}{|c|}{ Table 3: Current account balances as a percentage of GDP, 2001-2005 } \\
\hline Germany & $\mathbf{2 0 0 1}$ & $\mathbf{2 0 0 2}$ & $\mathbf{2 0 0 3}$ & $\mathbf{2 0 0 4}$ & $\mathbf{2 0 0 5}$ \\
\hline France & 0.2 & 2.3 & 2.2 & 3.8 & 4.1 \\
\hline Italy & 1.6 & 0.9 & 0.4 & -0.4 & -1.6 \\
\hline Spain & -0.1 & -0.8 & -1.3 & -0.9 & -1.5 \\
\hline & -3.9 & -3.3 & -3.6 & -5.3 & -7.7 \\
\hline Austria & & & & & \\
\hline Belgium & -1.9 & 0.3 & -0.5 & 0.3 & -0.4 \\
\hline Finland & 3.4 & 4.6 & 4.1 & 3.3 & 1.4 \\
\hline Greece & 7.2 & 7.6 & 3.8 & 5.3 & 3.5 \\
\hline Ireland & -8.1 & -7.5 & -7.2 & -6.3 & -7.0 \\
\hline Netherlands & -0.6 & -1.0 & 0.0 & -0.8 & -1.5 \\
\hline Portugal & 2.4 & 2.9 & 2.8 & 3.3 & 5.8 \\
\hline & -8.4 & -8.0 & -0.9 & -3.6 & -6.7 \\
\hline Euro area & 0.1 & 0.7 & 0.3 & 0.5 & -0.2 \\
\hline UK & -2.2 & -1.6 & -1.5 & -2.0 & -1.8 \\
\hline Sweden & 4.4 & 5.3 & 7.5 & 8.2 & 7.1 \\
\hline Japan & 2.1 & 2.8 & 3.2 & 3.7 & 3.4 \\
\hline USA & -3.8 & -4.5 & -4.7 & -5.7 & -6.5 \\
\hline Source: OECD $(2005)$ & & \multicolumn{5}{l}{} \\
\hline
\end{tabular}

We assess the extent to which fiscal policy exerts a stabilising or destabilising influence on the business cycle by comparing changes in the output gap and the cyclically adjusted budget balancepotential GDP ratio (CBR) (Table 2). ${ }^{10}$ The output gap serves as an indicator of the current state of economic activity. If it is positive, capacity is outstripped, if it is negative, capacity is not fully utilised. Consequently, a positive change in the output gap indicates a cyclical upturn, whereas a negative change points to a cyclical downturn. If there is a positive (negative) change in the CBR, then structural deficits fall (rise) or structural surpluses rise (fall), and fiscal policy exerts a restrictive (expansive) stimulus on demand. If the CBR remains constant when there is a change in the output gap, fiscal policy is neither expansive nor restrictive and the automatic stabilisers are simply left to take effect.

Measured this way, in the face of an average annual fall in the output gap of 0.6 percent of GDP, Euro area fiscal policy was only slightly expansive with an average annual increase in the cyclically

\footnotetext{
${ }^{10}$ See Hein/Truger (2006b) for a more extensive discussion. It should be noted, that the cyclically adjusted measures can be criticised for a number of theoretical and empirical reasons (implicit acceptance of some medium-term stable equilibrium, endogeneity of potential output and budget balances, sensitivity to different methods) so that they should be interpreted with great care.
} 
adjusted budget deficit of 0.1 percent of GDP from 2001 to 2005. Furthermore, almost all of the expansive, counter-cyclical reaction occurred in 2001, when the fall in the output gap was small. In 2002 the expansion was hardly measurable and since 2003 , fiscal policy has even been slightly procyclically restrictive. The cumulated negative fiscal stimulus over the last three years amounted to 0.5 percent of GDP. In striking contrast to the European experience, US fiscal policy from 2001 to 2005 was very expansive with an average annual increase of the cyclically adjusted budget deficit of 0.9 percent. There has not been a single year with pro-cyclical fiscal restriction during the economic downturn. Since 2005, the second year with an improving output gap, U.S. fiscal policy has returned smoothly to careful restriction, again.

For the individual Euro area countries the picture is rather diverse (Table 2). The high growth countries Finland and Ireland both reacted in a strongly counter-cyclical way to the slowdown. Italy, France and Germany saw a slightly expansive fiscal policy over the whole period. However, in these countries the expansion almost exclusively occurred in the first years of the slowdown. After the countries faced excessive deficit problems, they all had to switch to pro-cyclical restriction despite the ongoing crisis. In the five remaining countries, Spain, Austria, Belgium, the Netherlands and Portugal, fiscal policy was pro-cyclically restrictive over the whole period from 2001 to 2005. With the exception of Spain, both the drop in the output gap as well as the negative pro-cyclical fiscal stimulus have been substantial in the countries concerned.

Thus, the SGP led to destabilising, pro-cyclical fiscal policy reactions to the post-2000 crisis in several countries. Almost all countries with excessive deficit problems stopped their initially expansive fiscal policy and were driven into pro-cyclical, restrictive measures as soon as their deficit had reached the 3 percent of GDP level. Without doubt, the resulting negative fiscal stance has contributed to the ongoing stagnation tendencies after 2000 within these countries and in the Euro area as a whole. Moreover, the growth divergences between the countries seem to have been reinforced.

Summing up so far, the Euro area has suffered from a too restrictive monetary policy which has especially hurt the slowly growing low inflation countries, in particular Germany. Wage development has been stability oriented on average over the whole currency union and would have allowed for a more growth oriented ECB policy. But there have been serious imbalances below the surface with wage developments in Germany putting increasing deflationary pressure on the Euro area. The SGP prevented fiscal policy in many countries from reacting in a counter-cyclical way and aggravated the crisis even further. This macroeconomic policy constellation has contributed to 
slow growth and high unemployment, in particular in Germany and some other countries mentioned above. The major obstacle for improved growth and higher employment seems to have been the ECB. That is the reason why we analyse ECB policies in more detail in the following section.

\section{Why has the ECB been so unfriendly to growth?}

In what follows we try to assess the determinants of ECB-policies since 1999 in order to get a deeper understanding of the reasons that drive the ECB to act - or not to act. We use quarterly data from ECB (2006), except for the output gap which is taken from OECD (2005) and the Federal funds rate which is from Federal Reserve Bank of New York (2006). ${ }^{11}$ The data cover the period between the first quarter of 1999 and the fourth quarter of 2005, if available. This means that we have only 28 observations at the maximum for each time series, which prevents the application of time series econometrics. Instead, we have to rely on simple OLS regressions, which is why the results below should be interpreted with great care. ${ }^{12}$

\section{1 'Naïve' Taylor-rule}

In the first step we estimate a 'naïve' Taylor-rule for the ECB since 1999, in which the ECB key interest rate $\left(\mathrm{i}^{\mathrm{ECB}}\right)$ is determined by the output gap and the inflation gap, calculated as the difference between the increase in the HICP and the ECB inflation target which is assumed to be 1.9 percent ('below, but close to, 2 percent', ECB 2003: 79). According to Taylor (1993), the Fed's interest rate (i) policy between 1987 and 1993 was determined by the 'equilibrium real interest rate' $\left(i^{r}\right)$, current inflation $(\hat{\mathrm{p}})$, the deviation of actual output $(\mathrm{Y})$ from potential output $\left(\mathrm{Y}^{\mathrm{p}}\right)$, i.e. the output gap, and by the deviation of actual inflation $(\hat{\mathrm{p}})$ from target inflation $\left(\hat{\mathrm{p}}^{\mathrm{T}}\right)$, i.e. the inflation gap:

$$
i_{t}=i_{t}^{r}+\hat{p}_{t}+\alpha_{1}\left(Y_{t}-Y^{p}\right)+\alpha_{2}\left(\hat{p}_{t}-\hat{p}^{T}\right)
$$

Taylor (1993) assumed that the equilibrium real interest rate and the inflation target was 2 percent each, and the values of $\alpha_{1}$ and $\alpha_{2}$ were 0.5 each, i.e. the Fed placed equal emphasis on the output gap and on the inflation gap. Here, the output gap is the deviation of actual output from trend

\footnotetext{
${ }^{11}$ We are well aware of Orphanides's $(2001,2003)$ convincing suggestion to use 'real time data' in order to assess monetary policies. However, since the ECB always stresses the medium term orientation of its policies and since our data only cover 28 quarters, we feel that our procedure is appropriate. It goes without saying that we will not interpret our results in an exactly quantitative but rather in a qualitative way.

${ }^{12}$ The variables we use are either growth rates or shares which should not have a unit root from an economic theory point of view. However, the Augmented Dickey Fuller (ADF) test does not confirm this presumption for each time series under consideration. Although the ADF test is known to have only low power when applied to small samples, this is another reason for carefully interpreting of our results.
} 
output, which increased by 2.2 percent per year. Taylor then showed that the Federal funds rate indeed followed the rate of interest calculated according to equation (1). Reviewing the rich amount of literature on monetary policy rules which has emerged during the 1990s, Taylor (1999) confirmed the robustness of simple rules like the one he had proposed originally and also recommended such a rule for the ECB. ${ }^{13}$

\begin{tabular}{|c|c|c|c|}
\hline \multicolumn{4}{|c|}{ Table 4: The ECB's Taylor rule } \\
\hline & $(1)$ & (2) & (3) \\
\hline ECB key interest rate & $i^{\mathrm{ECB}} \mathrm{t}^{\mathrm{EC}}$ & $i^{\mathrm{ECB}} \mathrm{t}-1$ & $i^{\mathrm{ECB}} \mathrm{t}-1$ \\
\hline $\mathrm{C}$ & $2.90 * * *$ & $2.84 * * *$ & $1.27 *$ \\
\hline t-statistics & 35.30 & 21.32 & 6,44 \\
\hline$\overline{\mathrm{OG}_{\mathrm{t}}}$ & $0.75^{* * *}$ & $0.69 * * *$ & $0.39 * * *$ \\
\hline t-statistics & 11.52 & 7.53 & 6.93 \\
\hline $\mathrm{INFG}_{\mathrm{t}}$ & 0.20 & $0.51^{*}$ & $0.44 * * *$ \\
\hline t-statistics & 1.04 & 1.74 & 3.57 \\
\hline$i^{\mathrm{ECB}}{ }_{\mathrm{t}-2}$ & & & $0.52 * * *$ \\
\hline t-statistics & & & 8.02 \\
\hline Adj.R-squared & 0.90 & 0.81 & 0.96 \\
\hline DW & 0.71 & 0.88 & 1.77 \\
\hline $\mathrm{N}$ & 28 & 27 & 26 \\
\hline \multicolumn{4}{|c|}{$\begin{array}{l}\text { Notes: } i^{\mathrm{ECB}} \text { : ECB key interest rate at the end of quarter, percent; C: constant, } \\
\text { OG: output gap, percentage points; INFG: inflation gap, HCPI growth minus } \\
1.9 \text { percent as ECB inflation target, percentage points }\end{array}$} \\
\hline \multicolumn{4}{|c|}{$\begin{array}{l}\text { Significance: } * * * 1 \text { percent, } * * 5 \text { percent level, } * 10 \text { percent level, Newey- } \\
\text { West heteroskedasticity consistent coefficient covariance } \\
\text { Software: EViews } 5.1 \\
\text { Data sources: ECB (2006), OECD (2005) (ecowin), authors' calculations }\end{array}$} \\
\hline
\end{tabular}

Our estimation results of a 'naïve' Taylor rule for the ECB are shown in Table 4. We find that the current output gap (OG) has affected ECB's policies in the expected way, whereas the current inflation gap (INFG) has not (Table 4, estimation (1)). However, it is by now well known that central banks respond to expected inflation and output gaps (Clarida/Gali/Gertler 1998, 2000). If we assume that the ECB policies are 'forward looking' and that they respond to rationally expected future inflation and future output gaps one quarter ahead, also the inflation gap has a positive

\footnotetext{
${ }^{13}$ For estimation results of monetary policy rules for the Federal Reserve and other central banks see for example Clarida/Gali/Gertler $(1998,2000)$. These rules are of the 'forward looking' type, see below. For a detailed analysis of the monetary policy of the Federal Reserve see Weller (2002) and Thorbecke (2002). For the Bank of England see Mihailov (2006).
} 
impact on the ECB key interest rate, albeit statistically less significant than the output gap (Table 4, estimation (2)).

$$
\mathrm{i}_{\mathrm{t}-1}^{\mathrm{ECB}}=\mathrm{f}\left(\mathrm{OG}_{\mathrm{t}}, \mathrm{INFG}_{\mathrm{t}}\right),
$$

From the estimated constants we can also calculate the underlying 'equilibrium real interest rate', which is slightly below 1 percent given that actual inflation has been slightly above 2 percent on average since 1999. This value is considerably below what is usually assumed to be the 'equilibrium real interest rate' in Taylor rules, but similar to what Arestis/Chortareas (2006), applying Taylor rules to the ECB since 1999, have assumed to be the 'equilibrium real interest rate' perceived by the ECB.

Our estimations, however, suffer from the omitted variable problem, which is indicated by the Durbin-Watson statistics in Table 4. Therefore, we follow the common strategy in the literature and add interest rate smoothing to the estimated equations. We assume that the ECB does not violently respond to deviations of inflation and output from target values, but that it acts in a gradual way in order to smooth out real as well as expectation effects:

$$
i_{t-1}^{E C B}=f\left(O G_{t}, I N F G_{t}, i_{t-2}^{E C B}\right) .
$$

As estimation (3) in Table 4 shows, interest rate smoothing improves our results remarkably. The present ECB key interest rate is significantly affected by the rate of the previous quarter. The output gap and the inflation gap are highly significant and have a similar quantitative impact on ECB policies.

\subsection{Expanded Taylor-rule}

Interest rate smoothing is only one statistical alternative to improve regression results in the face of the omitted variable problem. A theoretically more interesting alternative is to introduce further determinants into the equation which might explain monetary policy action, in particular those variables which are under control of the other macroeconomic policy actors. We add unit labour cost growth (ULC) as an indicator for the effects of wage bargaining, cyclically adjusted fiscal balances as percentage of potential GDP (FBS) as an indicator for the fiscal policy stance, the USdollar-euro-exchange rate (ER) and the Federal funds rate $\left(\mathrm{F}^{\mathrm{FED}}\right)$ in order to cover the effects of financial markets and US monetary policies. With the exception of the Federal funds rate, these 
variables can be found in what the ECB (2003: 87-89) in the 'two-pillar approach' calls 'economic analysis', which is relevant for the ECB's assessment of the short- to medium term risks for price stability.

We refrain from introducing monetary aggregates into our estimations because we consider the quantity of money to be an endogenous variable with respect to economic activity, following the post-Keynesian endogenous money view which by now has been accepted also in the New Consensus model. ${ }^{14}$ The growth rate of a monetary aggregate will be highly collinear with the development of real GDP-growth and hence the output gap. In the reformulated monetary policy strategy, the ECB (2003: 89-92) has also downgraded the relevance of 'monetary analysis'. Having formerly been the first pillar, it is by now only the second pillar within the ECB's 'two-pillarapproach', serving as a means of 'cross-checking'. A long-term relationship between monetary aggregates and inflation is still assumed, but the ECB has no monetary target, and also the reference value for M3 is no longer reviewed on an annual basis. The ECB (2003: 91) stresses that there is no direct link between the development of M3 and monetary policy decisions. The relation between M3 and the interest rate decisions is hence rather vague, from the ECB's point of view, although the ECB still believes that inflation is a monetary phenomenon in the long run (see also Issing 2005). ${ }^{15}$

We apply a general to specific method and add all the additional variables to the equation. Then we drop those variables which are not significant at the 10 percent level and re-estimate the equation. We start with the following equation: ${ }^{16}$

$$
i_{t-1}^{E C B}=f\left(O_{t}, I N F G_{t}, U L C_{t}, F B S_{t}, E R_{t}, i_{t}^{\text {FED }}\right) .
$$

As can be seen from estimation (4) in Table 5, rationally expected unit labour cost growth as a major determinant of inflation and the federal funds rate have also affected ECB policies in the expected positive way. The significance of the Federal funds rate improves, if we assume that the

\footnotetext{
${ }^{14}$ On post-Keynesian monetary theory see Lavoie (1984, 1992: 149-216), Moore (1988) and Fontana (2003). On the New Consensus model see Goodfried/King (1997), Clarida/Gali/Gertler (1999), Romer (2000) and Carlin/Soskice (2006).

${ }^{15}$ The 'two-pillar-approach' may therefore send different and contradicting signals to market participants. This questions the credibility of the ECB's monetary strategy (see Arestis/Chortareas 2006).

${ }^{16}$ We also tried equation (4) with interest rate smoothing, but did not find any significant impact of the additional variables, so that we essentially returned to equation (3).
} 


\begin{tabular}{|c|c|c|c|c|c|}
\hline \multicolumn{6}{|c|}{ Table 5: Determinants of the ECB's key interest rate: the Taylor rule expanded } \\
\hline & $(4)$ & $(5)$ & $(6)$ & $(7)$ & $(8)$ \\
\hline ECB key interest rate & $i^{\mathrm{ECB}} \mathrm{t}-1$ & $i^{\mathrm{ECB}}{ }_{\mathrm{t}-1}$ & $i^{\mathrm{ECB}} \mathrm{t}-1$ & $i^{\mathrm{ECB}} \mathrm{t}-1$ & $i^{\mathrm{ECB}} \mathrm{t}-1$ \\
\hline $\mathrm{C}$ & 2.09 & $1.50 * * *$ & 0.02 & $-1.85^{* *}$ & $-4.38 * * *$ \\
\hline t-statistics & 1.10 & 4.94 & 0.04 & -2.13 & -3.87 \\
\hline $\mathrm{OG}_{\mathrm{t}}$ & $0.48^{* *}$ & $0.40 * * *$ & & $0.31 * *$ & \\
\hline t-statistics & 2.32 & 4.74 & & 2.80 & \\
\hline $\mathrm{GDP}_{\mathrm{t}}$ & & & $0.29 *$ & & 0.10 \\
\hline t-statistics & & & 1.77 & & 0.70 \\
\hline $\mathrm{INFG}_{\mathrm{t}}$ & $0.43^{* * *}$ & $0.53 * * *$ & $0.80^{* * *}$ & $0.67 * * *$ & $0.88 * * *$ \\
\hline t-statistics & 3.03 & 4.90 & 8.61 & 3.36 & 4.67 \\
\hline $\mathrm{ULC}_{\mathrm{t}}$ & $0.46^{* *}$ & $0.51 * * *$ & $0.92 * * *$ & & \\
\hline t-statistics & 2.50 & 5.00 & 5.61 & & \\
\hline $\mathrm{NW}_{\mathrm{t}}$ & & & & $1.71 * * *$ & $2.54 * * *$ \\
\hline t-statistics & & & & 5.78 & 5.74 \\
\hline$i^{\text {FED }}$ & $0.13^{* *}$ & & & & \\
\hline t-statistics & 2.43 & & & & \\
\hline $\mathrm{i}_{\mathrm{iED}}^{\mathrm{FED}}$ & & $0.19 * * *$ & $0.28 * * *$ & $0.21 * * *$ & $0.33^{* * *}$ \\
\hline t-statistics & & 3.72 & 3.84 & 3.71 & 4.60 \\
\hline FBS & -0.05 & & & & \\
\hline t-statistics & -0.63 & & & & \\
\hline ER & -0.39 & & & & \\
\hline t-statistics & -0.24 & & & & \\
\hline \begin{tabular}{|l} 
Adj. R-squared \\
\end{tabular} & 0.88 & 0.91 & 0.86 & 0.90 & 0.87 \\
\hline DW & 1.59 & 1.62 & 1.83 & 1.72 & 1.69 \\
\hline $\mathrm{N}$ & 26 & 26 & 26 & 27 & 27 \\
\hline $\begin{array}{l}\text { Notes: }{ }^{\mathrm{ECB}} \text { : ECB key int } \\
\text { real GDP growth rate, pe } \\
\text { percentage points; ULC: } \\
\text { increase in percent; } \mathrm{i}^{\mathrm{FED}} \text { : } \\
\text { financial balances in per }\end{array}$ & $\begin{array}{l}\text { ate at the e } \\
\text { INFG: inf } \\
\text { al unit lab } \\
\text { al funds ra } \\
\text { p potential }\end{array}$ & $\begin{array}{l}\text { uarter, per } \\
\text { ap, HCPI \& } \\
t \text {, annual in } \\
\text { end of qu } \\
\text { R: exchan }\end{array}$ & $\begin{array}{l}\text { constant, } \mathrm{O} \\
\text { minus } 1.9 \mathrm{p} \\
\text { in percent; } 1 \\
\text { ercent, FBS } \\
\text { US-\$/€ }\end{array}$ & $\begin{array}{l}\text { put gap, per } \\
\text { sCB infl } \\
\text { gotiated wo } \\
\text { ally adjuste }\end{array}$ & $\begin{array}{l}\text { ae points; GD } \\
\text { arget, } \\
\text { idex, annual } \\
\text { ernment }\end{array}$ \\
\hline $\begin{array}{l}\text { Significance: } * * * 1 \text { perc } \\
\text { covariance } \\
\text { Software: EViews } 5.1 \\
\text { Data sources: ECB }(200\end{array}$ & $\begin{array}{l}5 \text { percent, } \\
\text { CD (2005) }\end{array}$ & $\begin{array}{l}\text { ercent leve } \\
\text { in), authors }\end{array}$ & $\begin{array}{l}\mathrm{y} \text {-West hete } \\
\text { lations }\end{array}$ & asticity con & coefficient \\
\hline
\end{tabular}


ECB does not react in a forward looking manner with respect to this variable, but rather responds to actual Fed policies (estimation (5)). ${ }^{17}$

But neither the rationally expected structural fiscal balances nor the US-dollar-euro-exchange rate have had a significant impact on ECB policies. ${ }^{18}$ The ECB does not seem to have responded to fiscal policies in the Euro area. And although the ECB has been affected by the Fed policy, we have no direct impact of the US-dollar-euro-exchange rate on ECB policies.

$$
i_{t-1}^{E C B}=f\left(O G_{t}, I N F G_{t}, U L C_{t}, i_{t-1}^{F E D}\right) .
$$

Taken together, from our 'best fit' estimation (5) in Table 5, we get that the ECB's interest rate policy is mainly determined by the rationally expected values of the output gap, the inflation gap, and unit labour cost growth with similar weight, and that there is also a smaller impact of the current Federal funds rate.

\subsection{Some problems with (expanded) Taylor rules}

Finally, we modify our 'best fit'-estimation (5) in order to address some problems related to Taylor rules. The first problem is the endogeneity problem with respect to the output gap as an indicator for real economic activity. Potential output is determined by capital stock and productivity, and past investment affects present capital stock and present productivity. The latter requires that technical progress is embodied in capital stock. Therefore, past investment determines present potential output. ${ }^{19}$ If overly restrictive monetary policies have driven down investment in the past this will reduce current potential output and, with present output given, the output gap. Current monetary policy may therefore seem to be more responsive to output than it would have been the case if past monetary policies had been more expansive. The estimated coefficient for the output gap may therefore depend on past monetary policies in an inverse way: Expansive monetary policies in the past increasing present potential output and the output gap make present monetary policies look less responsive to output, and vice versa. Instead of the output gap we therefore insert real GDP growth into the equation to be estimated, because real GDP growth (or the deviation of real GDP growth from an exogenous real GDP growth trend) does not suffer from the above endogeneity problem:

\footnotetext{
${ }^{17}$ Applying a Granger causality test, Belke/Gros (2005) find that after September 11, 2001, the Federal funds rate has Granger caused the ECB interest rate but the ECB interest rate has not Granger caused the Federal funds rate. Before September 11, 2001, there was mutual Granger causality.

${ }^{18}$ We also tried different lags without getting a statistically significant relationship.

${ }^{19}$ On the endogeneity of potential output or 'natural growth' see Arestis/Sawyer (2004, 2005), Lavoie (2004) and LeonLedesma/Thirlwall (2002).
} 


$$
\mathrm{i}_{\mathrm{t}-1}^{\mathrm{ECB}}=\mathrm{f}\left(\mathrm{GDP}_{\mathrm{t}}, \mathrm{INFG}_{\mathrm{t}}, \mathrm{ULC}_{\mathrm{t}}, \mathrm{i}_{\mathrm{t}-1}^{\mathrm{FED}}\right) .
$$

The results of estimation (6) in Table 5 show, that real GDP growth as a determinant of the ECB key interest rate is statistically less significant than the output gap in the previous estimations. And it also becomes clear that real GDP growth has been less important for the ECB than the inflation gap or unit labour cost growth. Therefore, using the output gap as a 'real economy' determinant of ECB policies may be misleading.

Unit labour cost growth as an indicator for inflationary pressure of wage setting may also suffer from a similar endogeneity problem as the output gap. Unit labour cost growth is affected by labour productivity growth, and with technical progress embodied in capital stock, productivity is affected by investment in capital stock. Therefore, restrictive monetary policies in the past depressing investment may cause current unit labour costs to rise without any change in the tendency of labour unions wage setting. Therefore, we replace unit labour cost growth as a determinant of ECB policies by the annual increase in negotiated wages as a direct outcome of wage bargaining. ${ }^{20}$

$$
\mathrm{i}_{\mathrm{t}-1}^{\mathrm{ECB}}=\mathrm{f}\left(\mathrm{OG}_{\mathrm{t}}, \mathrm{INFG}_{\mathrm{t}}, \mathrm{NW}_{\mathrm{t}}, \mathrm{i}_{\mathrm{t}-1}^{\mathrm{FED}}\right)
$$

As can be seen from estimation (7) in Table 5, the increase in negotiated wages is a highly significant determinant of the ECB key interest rate. The ECB seems to put high emphasis on wage bargaining when setting the key interest rate. The inflation gap still has a major impact, and the output gap has again the expected effect, but is statistically less significant. The influence of the Fed's interest rate policy remains significant as well.

$$
\mathrm{i}_{\mathrm{t}-1}^{\mathrm{ECB}}=\mathrm{f}\left(\mathrm{GDP}_{\mathrm{t}}, \mathrm{INFG}_{\mathrm{t}}, \mathrm{NW}_{\mathrm{t}}, \mathrm{i}_{\mathrm{t}-1}^{\mathrm{FED}}\right) .
$$

Replacing the output gap in estimation (7) by real GDP growth in order to circumvent the endogeneity problem with respect to this variable renders the real variable in the reaction function statistically insignificant (Table 5, estimation (8)). This underlines our previous result that the output gap may be a misleading indicator for the responsiveness of monetary policy to real economic activity.

\footnotetext{
${ }^{20}$ We also tried the increase in compensation per employee, which, however was not statistically significant and made our estimation considerably worse.
} 


\section{Estimation results and the course of ECB policies since 1999}

Our estimation results can now be applied to the course of ECB policies since 1999. According to our estimations the ECB has attached high importance to expected inflation (HICP growth) and on the inflation gap. The ECB has raised interest rates when inflation exceeded its target of below, but close to, 2 percent. Since HICP growth has exceeded the ECB's target for considerable periods of time since 1999 (Figure 3), this has given monetary policies a restrictive stance which has mainly contributed to the 2000/2001 growth slowdown and the slow recovery since then. Note, however, that core inflation (HICP excluding energy and unprocessed food) has been well below 2 percent since the first quarter of 2005 and that the ECB has started to increase interest rates in the third quarter of 2005 despite core inflation remaining low.

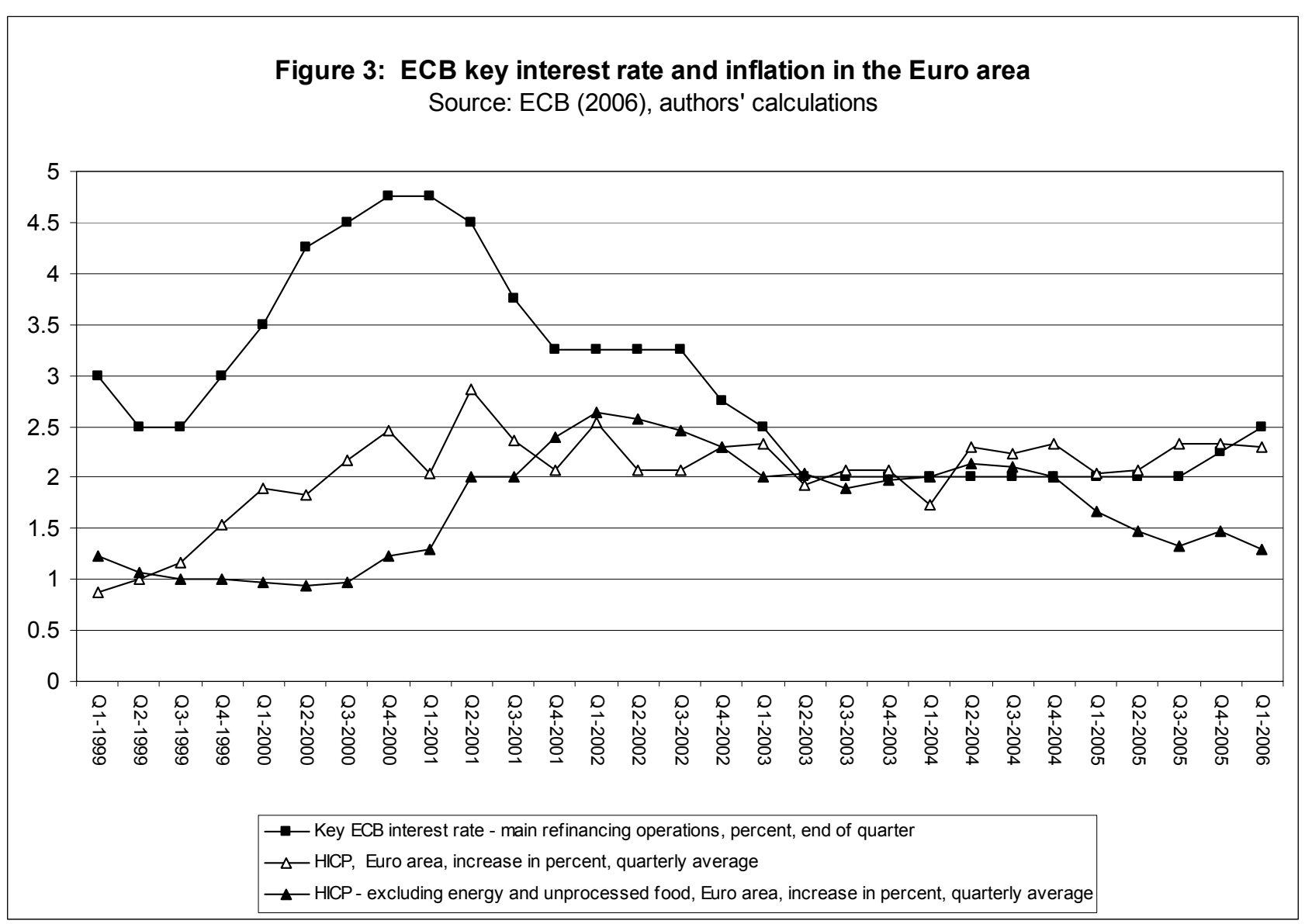

We have found that the ECB has also put high emphasis on unit labour cost growth and on the development of negotiated wages. In particular unit labour cost growth has indeed been a problem for the inflation target in 2001/2002 and in 2003 (Figure 4). The main reason for this, however, has been the drop in productivity growth during the economic downswing since late 2000 and the weak 
recovery since then, both caused by ECB policies (Figure 5). Since early 2004 neither negotiated wages nor unit labour cost growth rates have been a challenge for the ECB inflation target.

Figure 4: ECB key interest rate, unit labour costs and negotiated hourly wages in the Euro area

Source: ECB (2006), authors' calculations

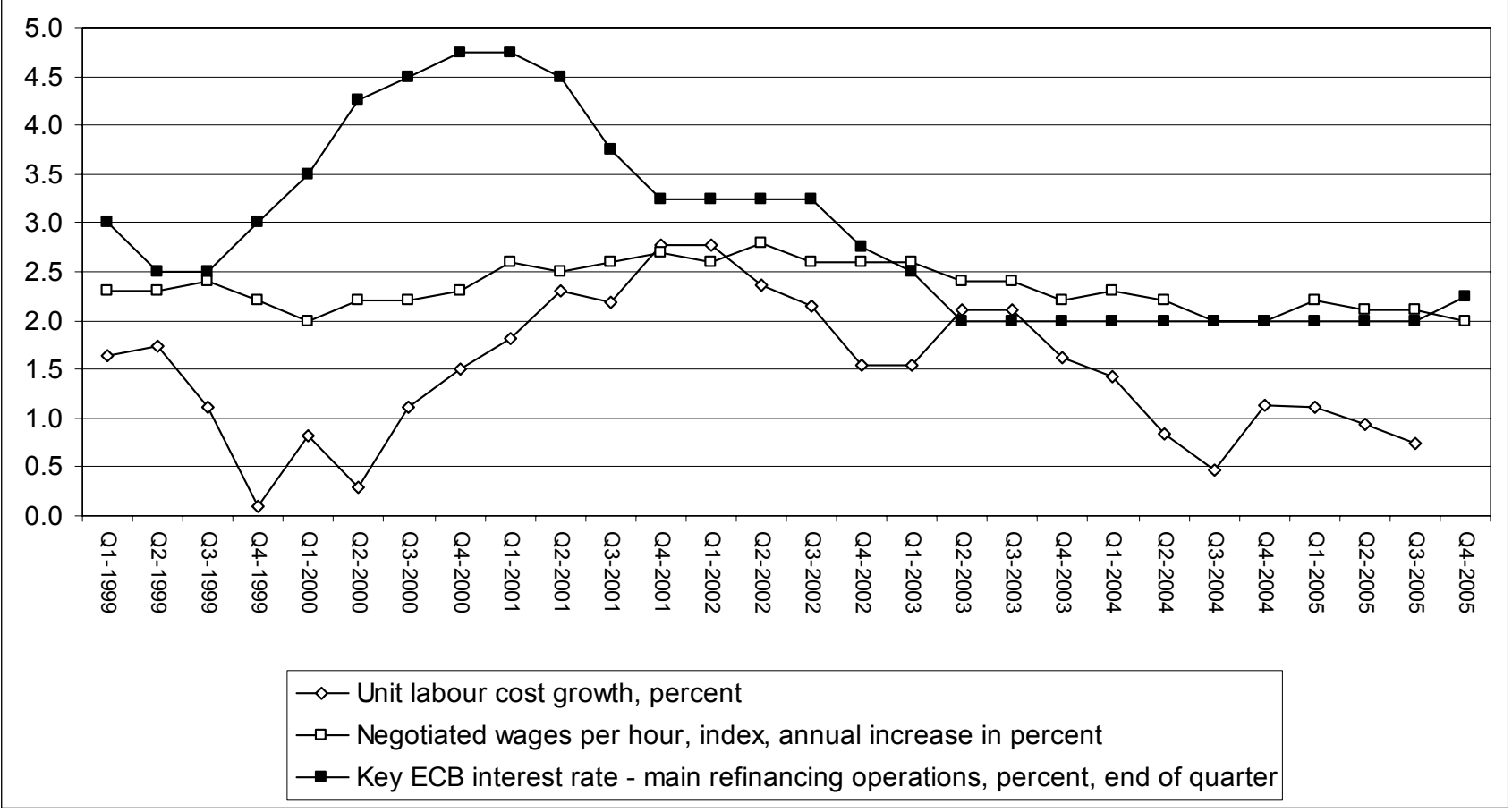

Figure 5: Unit labour costs, compensation per employee, and labour productivity in the Euro area, annual growth rate Source: ECB (2006)

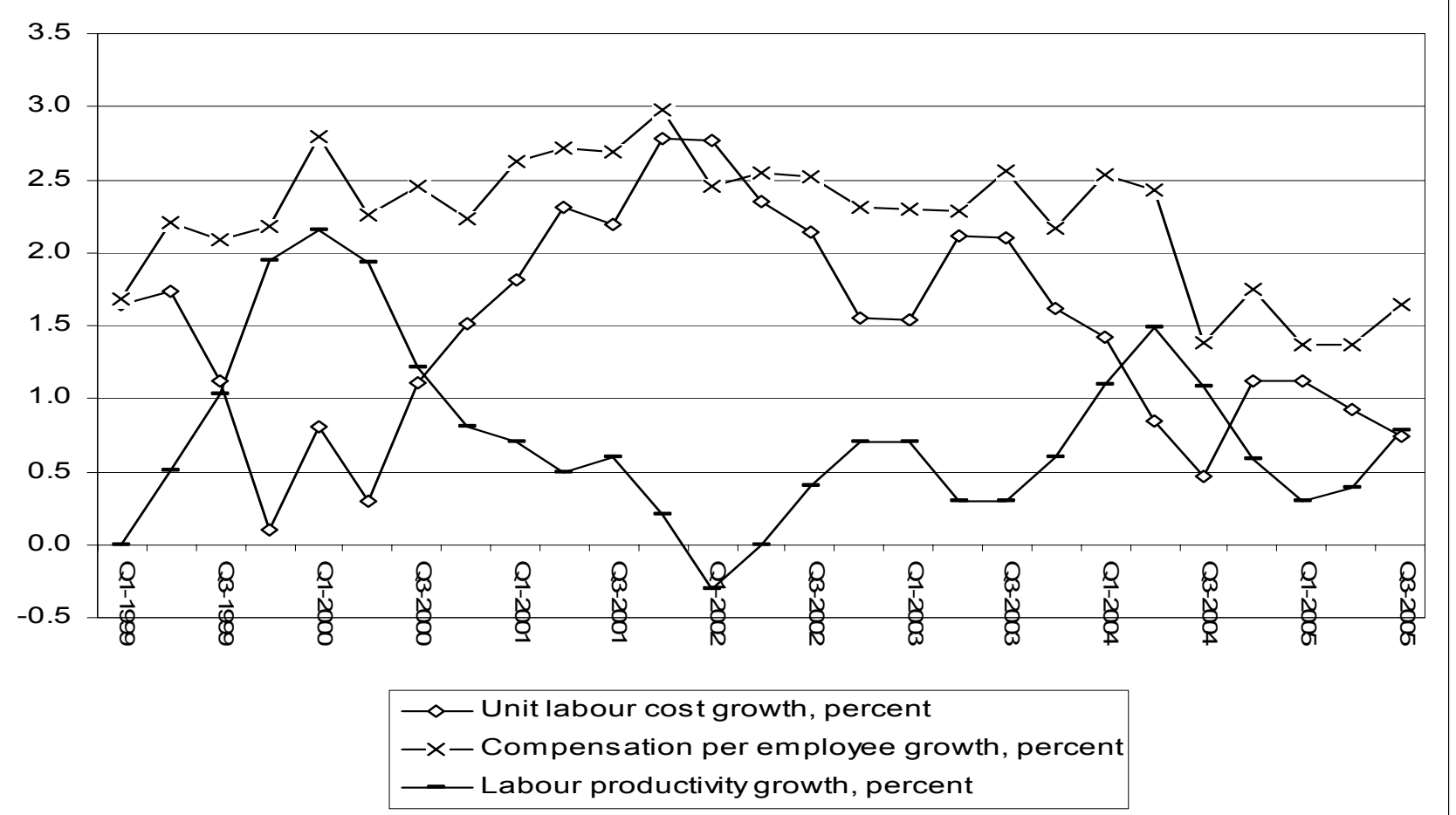


According to our results, the ECB has also responded to the expected output gap. If we take into account the endogenous nature of potential output and hence the output gap, and consider the impact of actual real economic activity on ECB policies, we have found that real GDP growth has been hardly significant or even insignificant. Indeed, the ECB has responded very slowly and very little to the recession in 2000/2001 and has also not taken action in the face of the recent slow growth and even persistent underutilisation of productive capacity since early 2003 (Figure 6). On the contrary, in late 2005 the ECB has started to raise interest rates in the face of imperilled growth and a persistent negative output gap, which is only slowly improving.

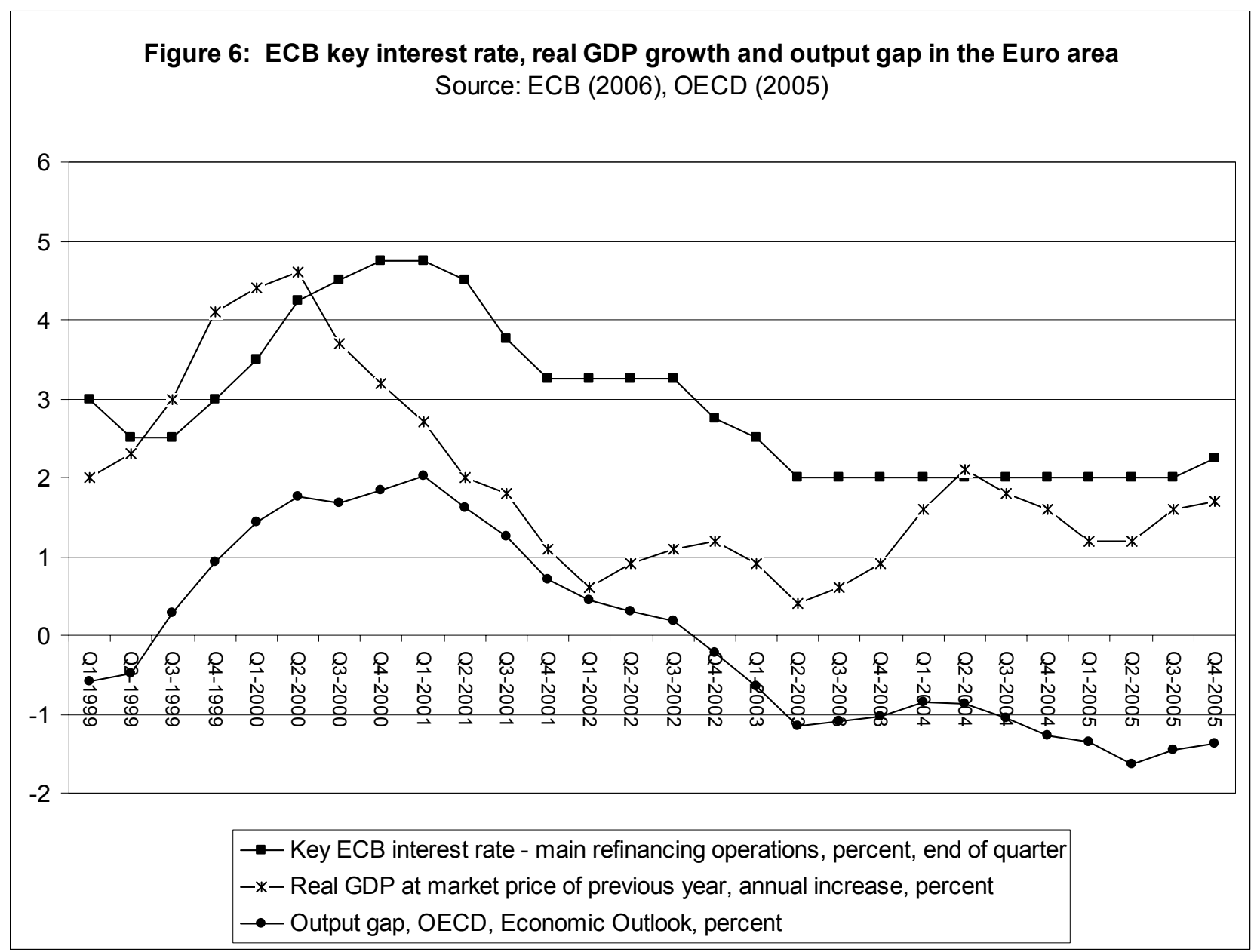

Finally, we have found that the ECB has been influenced by the Fed's interest rate policy. The ECB has followed the Fed raising interest rates in 1999/2000 (Figure 7). When the Fed cut rates in 2000/2001, the ECB initially has been reluctant to follow but has finally also reduced the ECB key rate, albeit to a much lesser extent. Currently, the ECB seems to follow the Fed again, which already in 2004 started to raise interest rates. From our analysis, however, it is not clear why the ECB has been affected by the Fed's monetary policy. Some authors have speculated that the ECB has used its interest rate tool in order to defend the euro-dollar-exchange rate (Bibow 2002, 
Heine/Herr 2004: 188-196). However, we have not found any direct impact of the exchange rate on ECB policies. Other authors have supposed that in an environment of global uncertainty the ECB follows the Fed, because the Fed is more effective in dealing with macroeconomic shocks (Belke/Gros 2003). In a sense, the ECB tries to take advantage of the 'option value of waiting', it is argued. This, however, is not easy to reconcile with the results of a meta-analysis of empirical studies on monetary policies by De Grauwe/Costa Storti (2004) who find that the long-run output effects of monetary policies have been larger in the Euro area than in the USA. But here is not the place to pursue this problem any further.

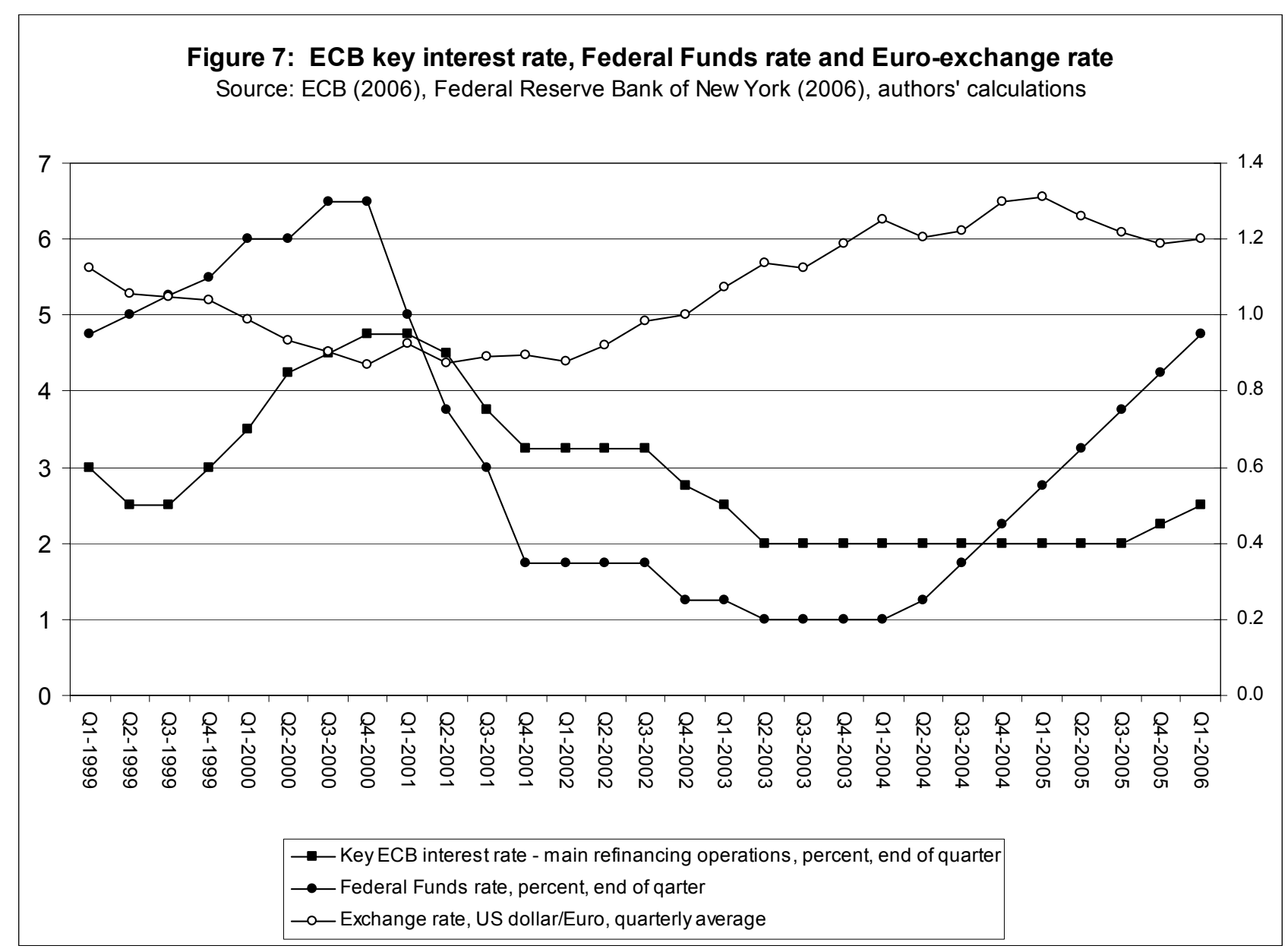

Considering the ECB policies against the background of our estimation results, neither the development of the output gap, nor the development of unit labour costs or negotiated wages can explain the most recent interest rate hikes. In the most recent past, it seems that the ECB has been driven particularly by the failure to achieve its overly ambitious inflation target and by the Fed's interest rate policy. 


\section{Economic policy conclusion}

Our analysis has confirmed that it is the ECB's attaching too high importance to low inflation which is a major problem for growth and employment in the Euro area. This has two aspects. First, the ECB's inflation target is too ambitious for a heterogeneous monetary union with divergent unit labour cost growth and hence persistent inflation differentials. Second, the ECB is too exclusively occupied with inflation and wage developments and puts too low an emphasis on the development of real variables. Since further progress with the coordination of wage bargaining in the Euro area along the formula 'national long-run productivity growth plus ECB inflation target' cannot be expected for the near future, it will be impossible to further reduce average unit labour cost growth and inflation in line with the ECB's target without driving the largest economy, Germany, into deflation. In order to improve growth and employment it is therefore urgently required that the ECB raises its inflation target in order to limit the risks of deflation in the largest economy of the Euro area. And the ECB should also place higher emphasis on the development of real variables, thereby taking into account that the development of the output gap might be misleading as an indicator. Given the experience made during the last seven years, however, this might require major institutional reforms in the Euro area macroeconomic policy framework determined by the European Treaty, in particular a change in the ECB's hierarchical mandate and the ECB's independence in defining what price stability means.

\section{References}

Allsopp, C., Vines, D. (1998): The assessment: Macroeconomic policy after EMU, Oxford Review of Economic Policy, 14 (3): 1-23.

Arestis, P. et al. (2001): An alternative stability pact for the European Union, Cambridge Journal of Economics, 25: 113-130.

Arestis, P., Chortareas, G. (2006): Monetary policy in the euro area, Journal of Post Keynesian Economics, 28: 371-394.

Arestis, P., Sawyer, M. (2004): Re-examining Monetary and Fiscal Policy for the $21^{\text {st }}$ Century, Cheltenham: Edward Elgar.

Arestis, P., Sawyer, M. (2005): Aggregate demand, conflict and capacity in the inflationary process, Cambridge Journal of Economics, 29: 959-974.

Belke, A., Gros, D. (2003): Does the ECB follow the Fed?, Applied Economics Quarterly, 49: 195-212.

Bernanke, B., Gertler, M. (1995): Inside the black box: the credit channel of monetary policy transmission, Journal of Economic Perspectives, 9: 27-48.

Bhaduri, A., Marglin, S. (1990): Unemployment and the real wage: the economic basis for contesting political ideologies, Cambridge Journal of Economics, 14: 375-393. 
Bibow, J. (2002): The monetary policies of the European Central Bank and euro's (mal)performance: a stability-oriented assessment, International Review of Applied Economics, 16: 31-50.

Bibow, J. (2005a): Europe's quest for monetary stability: central banking gone astray, The Levy Economics Institute of Bard College, Working Paper No. 428.

Bibow, J. (2005b): Bad for Euroland, worse for Germany - the ECB's record, The Levy Economics Institute of Bard College, Working Paper No. 429.

Carlin, W., Soskice, D. (2006): Macroeconomics. Imperfections, Institutions and Policies, Oxford: Oxford University Press.

Cecchetti, S.G. (1995): Distinguishing theories of the monetary transmission mechanism, Federal Reserve Bank of St. Louis Review, 77 (3): 83-97.

Clarida, R., Gali, J., Gertler, M. (1998): Monetary policy rules in practice. Some international evidence, European Economic Review, 42: 1033-1067.

Clarida, R., Gali, J., Gertler, M. (1999): The science of monetary policy: a New Keynesian perspective, Journal of Economic Literature, 37: 1661-1707.

Clarida, R., Gali, J., Gertler, M. (2000): Monetary policy rules and macroeconomic stability: evidence and some theory, The Quarterly Journal of Economics, 115: 147-180.

ECB (2003): The Outcome of the ECB's Evaluation of its Monetary Strategy, Monthly Bulletin, June: 79-92.

ECB (2006): Monthly Bulletin, Data, http://www.ecb.int/stats/services/downloads/html/index.en.html.

De Grauwe, P., Costa Storti, C. (2004): The effects of monetary policy: a meta-analysis, CESifo Working Paper No. 1224, Munich: CESifo.

Eichengreen, B. (1998): European monetary unification: A tour d'horizon, Oxford Review of Economic Policy, 14 (3): 24-40.

European Commission (2005): Annual macro-economic database (AMECO), December 2005, http://europa.eu.int/comm/economy_finance/indicators/annual_macro_economic_database/ameco_en.ht $\mathrm{m}$.

Federal Reserve Bank of New York (2006): Historical Changes of the Target Federal Funds and Discount Rates, http://www.newyorkfed.org/markets/statistics/dlyrates/fedrate.html.

Fontana, G. (2003): Post Keynesian approaches to endogenous money: a time framework explanation, Review of Political Economy, 15: 291-314.

Fritsche et al. (2005): Macroeconomic regime and economic development: the case of the USA, in: Hein, E. et al. (eds.), Macroeconomic Policy Coordination in Europe and the Role of the Trade Unions, Brussels: ETUI.

Goodfried, M., King, R. (1997): The New Neoclassical Synthesis and the role of monetary policy, NBER Macroeconomic Annual, 231-283.

Hein, E. (2002): Monetary policy and wage bargaining in the EMU: restrictive ECB policies, high unemployment, nominal wage restraint and inflation above the target, Banca Nazionale del Lavoro Quarterly Review, 55: 299-337.

Hein, E. (2006a): Wage bargaining and monetary policy in a Kaleckian monetary distribution and growth model: trying to make sense of the NAIRU, Intervention. Journal of Economics, forthcoming. 
Hein, E. (2006b): On the (in-)stability and the endogeneity of the 'normal' rate of capacity utilisation in a post-Keynesian/Kaleckian 'monetary' distribution and growth model, Indian Development Review, 4: 129-150.

Hein, E., Niechoj, T. (2006): Guidelines for sustained growth in the EU? The concept and the consequences of the Broad Economic Policy Guidelines, in: McCombie, J., Rodriguez, C. (eds.), Institutions, Public Policy and Governance, Basingstoke: Palgrave/Macmillan, forthcoming.

Hein, E., Schulten, T. (2004): Unemployment, wages and collective bargaining in the European Union, Transfer. European Review of Labour and Research, 10: 532-551.

Hein, E., Schulten, T., Truger, A. (2006): Deflation risks in Germany and the EMU: the role of wages and wage bargaining, in: Hein, E., Heise, A., Truger, A. (eds.), Wages, Employment, Distribution and Growth. International Perspectives, Basingstoke: Palgrave/Macmillan.

Hein, E., Truger, A. (2005a): European Monetary Union: nominal convergence, real divergence and slow growth?, Structural Change and Economic Dynamics, 16: 7-33.

Hein, E., Truger, A. (2005b): Macroeconomic coordination as an economic policy concept - opportunities and obstacles in the EMU, in: Hein, E., et al. (eds.), Macroeconomic Policy Coordination in Europe and the Role of the Trade Unions, Brussels: ETUI.

Hein, E., Truger, A. (2005c): What ever happened to Germany? Is the decline of the former European key currency country caused by structural sclerosis or by macroeconomic mismanagement?, International Review of Applied Economics, 19: 3-28.

Hein, E., Truger, A. (2005d): A different view of Germany's stagnation, Challenge. The Magazine of Economic Affairs, 48 (6): 64-94.

Hein, E., Truger, A. (2006a): Germany's post-2000 stagnation in the European context - a lesson in macroeconomic mismanagement, IMK Working Paper, 3/2006, Duesseldorf: Macroeconomic Policy Institute (IMK) in the Hans-Boeckler-Foundation.

Hein, E., Truger, A. (2006b): Fiscal policy and macroeconomic performance in the Euro area - lessons for the future, IMK Working Paper, 7/2006, Duesseldorf: Macroeconomic Policy Institute (IMK) in the Hans-Boeckler-Foundation.

Heine, M., Herr, H. (2004): Die Europäische Zentralbank. Eine kritische Einführung in die Strategie und Politik der EZB, Marburg: Metropolis.

Issing, O. (2005): The ECB and the euro - the first 6 years: A view from the ECB, Journal of Policy Modeling, 27: 405-420.

Lavoie, M. (1984): The endogenous flow of credit and the post-Keynesian theory of money, Journal of Economic Issues, 18: 771-797.

Lavoie, M. (1992): Foundations of Post Keynesian Economic Analysis, Aldershot: Edward Elgar.

Lavoie, M. (2004): The New Consensus on monetary policy seen from a Post-Keynesian perspective, in: Lavoie, M., Seccareccia, M. (eds.), Central Banking in the Modern World. Alternative Perspectives, Cheltenham: Edward Elgar.

Leon-Ledesma, M.A., Thirlwall, A.P. (2002): The endogeneity of the natural rate of growth, Cambridge Journal of Economics, 26: 441-459.

Mihailov, A. (2006): Operational independence, inflation targeting, and UK monetary policy, Journal of Post Keynesian Economics, 28: 395-422. 
Moore, B.J. (1988): Horizontalists and Verticalists: The Macroeconomics of Credit Money, Cambridge (Cambridge University Press).

$\begin{array}{llllll}\text { OECD (2005): Economic } & \text { Outlook, }\end{array}$ http://www.oecd.org/document/61/0,2340,en_2649_201185_2483901_1_1_1_1,00.html.

Orphanides, A (2001): Monetary policy rules based on real-time data, American Economic Review, 91: 964985.

Orphanides, A. (2003): Historical monetary policy analysis and the Taylor rule, Journal of Monetary Economics, 50: 983-1022.

Palley, T. (1998): Restoring prosperity: why the U.S. model is not the answer for the United States or Europe, Journal of Post Keynesian Economics, 20: 337-352.

Romer, D. (2000): Keynesian macroeconomics without the LM curve, in: Journal of Economic Perspectives, 14 (2): 149-169.

Sawyer, M. (2002): The NAIRU, aggregate demand and investment, in: Metroeconomica, 53: 66-94.

Solow, R. M. (2000): Unemployment in the United States and in Europe: a contrast and the reasons, IfoStudien, 46: 1-12.

Taylor, J.B. (1993): Discretion versus policy rules in practice, in: Carnegie Rochester Conference Series on Public Policy, 39: 195-214.

Taylor, J.B. (1999): The robustness and efficiency of monetary policy rules as guidelines for interest rate setting by the European central bank, Journal of Monetary Economics, 43: 655-679.

Taylor, J.B. (2000): Teaching modern macroeconomics at the principles level, American Economic Review, 90 (2): $90-94$.

Thorbecke, W. (2002): A dual mandate for the Federal Reserve System: the pursuit of price stability and full employment, Eastern Economic Journal, 28: 255-268.

Weller, C. (2002): What drives the Fed to act, Journal of Post Keynesian Economics, 24: 391-417. 
Publisher: Hans-Böckler-Stiftung, Hans-Böckler-Str. 39, 40476 Düsseldorf, Germany

Phone: +49-211-7778-331, IMK@boeckler.de, http://www.imk-boeckler.de

IMK Working Paper is an online publication series available at:

http://www.boeckler.de/cps/rde/xchg/hbs/hs.xls/31939.html

\section{ISSN: 1861-2199}

The views expressed in this paper do not necessarily reflect those of the IMK or the Hans-Böckler-Foundation.

All rights reserved. Reproduction for educational and non-commercial purposes is permitted provided that the source is acknowledged.
Hans Böckler Stiftung

Fakten für eine faire Arbeitswelt. 